\title{
Pressure ulcer dressings in critical patients: a cost analysis
}

\author{
Curativos de lesões por pressão em pacientes críticos: análise de custos \\ Los curativos de lesiones por presión en pacientes en estado crítico: análisis de costos
}

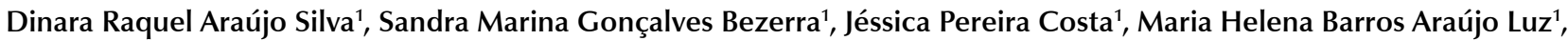
Vanessa Caminha Aguiar Lopes ${ }^{1}$, Lidya Tolstenko Nogueira ${ }^{1}$

How to cite this article:

Silva DRA, Bezerra SMG, Costa JP, Luz MHBA, Lopes VCA, Nogueira LT. Pressure ulcer dressings in critical patients: a cost analysis. Rev Esc Enferm USP. 2017;51:e03231. DOI: http://dx.doi.org/10.1590/S1980-220X2016014803231

${ }^{1}$ Universidade Federal do Piauí, Departamento de Enfermagem, Teresina, PI, Brazil.

\begin{abstract}
Objective: To assess the direct cost of dressings in pressure ulcer treatment. Method: This was a descriptive observational study conducted at an intensive care unit in the Northeast region of Brazil, between November and December 2015. Data were gathered using the Pressure Ulcer Scale for Healing and a form to characterize and assess costs. Values in Brazilian reais (BRL) were converted into U.S. dollars at the exchange rate of USD 0.26/ BRL. Univariate and bivariate analyses were conducted. Results: The sample consisted of 15 patients with at least stage 2 ulcers. There was a significant reduction in costs with dressing materials between the initial and final assessments $(p=0.002)$, with a mean of USD $11.9( \pm 7.4)$. The most common topical treatments used were essential fatty acids and papain. Conclusion: Cost reduction was proportional to the stage of pressure ulcer. The role of nurses in creating evidence-based care plans is crucial to improve care management.
\end{abstract}

DESCRIPTORS

Pressure Ulcer; Costs and Cost Analysis; Bandages; Nursing Care. 


\section{INTRODUCTION}

Pressure Ulcers (PUs) significantly impact patients, family members and health systems, in that they are recurring, debilitating and negatively impact quality of life by causing pain, suffering, increased length of hospital stay or even death. Furthermore, they require lasting treatment and are associated with high rates of morbidity, mortality, and costs ${ }^{(1)}$, especially those related to dressings.

Pressure ulcers are localized injuries to the skin and/or underlying tissues, usually over a bony prominence or in association with care devices, resulting from sustained pressure, or a combination of pressure and shear. Classification indicates the level of tissue injury: stage 1 , nonblanchable erythema on intact skin; stage 2, partial loss of skin thickness with exposed dermis; stage 3 , total loss of skin thickness; stage 4 , total loss of skin thickness and tissue loss; nonstageable, when there is nonvisible tissue loss; and deep tissue pressure ulcer, persistent and nonblanchable maroon, brown, or purple discoloration ${ }^{(2)}$.

Treatment for pressure ulcers incurs in high costs for health services, especially stage 3 and 4 , as they require a great amount of material and human resources. Audits conducted in public health services have shown that inconsistent wound care management practices and the use of outdated methods contribute to such high costs and ineffective outcomes ${ }^{(3)}$.

Health costs in Brazil are high and have been rising quickly, making it difficult to maintain the sustainability of health systems, which is intensified by the current global economic crisis. Managers, providers, funding agencies, authorities and users have been progressively concerned with costs and how they influence quality of service ${ }^{(4)}$.

Within the context of research, there is a shortage of quality evidence that indicate the profitability of interventions and poor methodological definition and structuring of economic assessment, with explanations about the unit of cost of the analysis, inclusions, and cost calculation. Thus, treatment is measured through a combination of clinical, economic and/or humanistic outcomes ${ }^{(5)}$.

The efficacy, effectiveness and efficiency of health services are aimed at optimizing care practices without losing sight of the cost perspective ${ }^{(6)}$. Economic assessment studies are important administrative and resource distribution tools to reduce costs for health systems and clients alike ${ }^{(7)}$.

In light of the above, the aim of the present study was to assess the direct costs of dressing materials used in PU treatment in an intensive care unit part of a university hospital in order to produce scientific knowledge on the topic, considering its relevance and impact on health management.

\section{METHOD}

This was an observational and analytical study conducted at a 10-bed intensive care unit (ICU) at a university hospital in the Northeast region of Brazil, between November and December 2015. Nonprobabilistic sampling was used and the inclusion criteria were: patients 18 years or older undergoing treatment for PU. Seven cases that did not require wound dressings or the ones that could not be observed completely, including one death and one transfer to another unit, were excluded. Thus, the sample consisted of 15 patients.
Data were collected using a three-part form: The first included sociodemographic (age, gender, marital status and education level) and general clinical data (clinical diagnosis, mobility, comorbidities, nutritional risk). Nutritional risk was assessed with the Nutritional Risk Screening tool, which is composed of two dimensions: nutritional condition and disease severity, measured on an ordinal scale from 0 to 3 . The final result was represented by the sum of the scores, and patients with values equal or higher than 3 were considered to be at nutritional risk ${ }^{(8)}$. The second section gathered data on wound characteristics, and the third presented a checklist with the materials used during procedures.

The researchers adopted the third edition of the Portuguese version of the Pressure Ulcer Scale for Healing (PUSH), validated in 2005, to monitor wound healing and thus assess the treatment given to patients. The scale evaluates three parameters: wound surface area ( 0 to 10 points, from 0 to greater than $24 \mathrm{~cm}^{2}$ ), exudate quantity ( 0 to 3 : none to heavy) and tissue type (0 to 4 : intact to necrotic). The total possible score ranges from 0 to 17 points. The assessment was longitudinal, in that higher scores indicated worsened conditions and lower scores indicated improved wound conditions ${ }^{(9)}$.

There is no minimum or maximum indication for applying the PUSH. The researchers established five observations per patient with a four-day interval between observations, so that differences could be perceived between assessments, considering the wound healing process ${ }^{(9)}$. During the time span covered in this study, each patient presented only one pressure ulcer.

First, patients undergoing PU treatment were identified through information on patient charts. Dressing changes were observed and the researchers recorded the materials used and measured the wounds with disposable rulers. The scale was applied to measure and classify wounds as per international panel guidelines ${ }^{(10)}$.

Each patient was assessed five times, totaling 75 observations. The observed dressing changes were carried out by nurses during patients' bed baths and all the beds used pneumatic mattresses.

Later, information was gathered from the hospital administration and financial sector about the unit cost of the materials used. Hospital materials were acquired through procurement processes, and the values considered for calculation in this study corresponded to the procurement in force at the time of the study. Original values in Brazilian Reais (BRL) were converted into U.S. dollars (USD) based on the exchange rate of BRL 1 to USD 0.26 (December 15, 2015).

The data were analyzed using the Statistical Package for the Social Sciences ${ }^{\oplus}$, version 18.0, generating descriptive statistics, such as mean, standard deviation, minimum and maximum values for quantitative variables and frequency for categorical values. For inferential analyses, the Shapiro-Wilk test was conducted to verify the normality of distribution and the Wilcoxon Signed-Rank test and Student's t-test were used to compare costs in relation to wound assessment, with a confidence interval of $95 \%$ and significance level set at $5 \%$. 
All stages of this study were abided by the ethical principles set forth in Resolution no. 466/2012 of the Brazilian National Health Council and by international standards for research with humans. The study was approved by a research ethics committee under ruling no. 1.197.638/2015.

\section{RESULTS}

Fifteen (100\%) patients participated in this study. Mean age was $52.2( \pm 20.7)$ years, ranging from 19 to 81 years. Most of the sample was composed of women (8, $53.3 \%)$, and $6(40 \%)$ were single, $3(20 \%)$ were married, 4 $(26.7 \%)$ were divorced, and $2(13.3 \%)$ were widowers. Most of the participants had not completed elementary school (9 (60\%). The most common reasons for ICU admission were respiratory problems $(7,46.6 \%)$, circulatory problems $(4,26.7 \%)$ and digestive problems $(4,26.6 \%)$. In addition to the baseline diagnosis, they presented the following comorbidities: systemic arterial hypertension (8, $53.3 \%)$, diabetes mellitus $(3,20.0 \%)$, chronic kidney failure (3, 20.0\%), systemic lupus erythematosus $(3,20.0 \%)$, and neurological disorders $(2,13.3 \%)$. Four patients $(26.6 \%)$ were at nutritional risk.
All the patients were bedridden with PUs located in the sacral region $(15,100 \%)$ : $6(40.0 \%)$ presented stage 2 ulcers, 6 (40.0\%) had stage 3 ulcers, 1 (6.7\%), stage 4, and $2(13.3 \%)$ were unstageable, with nonvisible tissue loss. At the first assessment, average wound surface area was 47.6 $( \pm 31.4) \mathrm{cm}^{2}$, with a minimum of 12 and a maximum of $126 \mathrm{~cm}^{2}$, while at the final assessment, surface areas ranged from $6 \mathrm{~cm}^{2}$ to $108 \mathrm{~cm}^{2}$, with a mean of $40.9( \pm 29.7)$, showing a statistically significant difference $(\mathrm{p}=0.007)$. PUSH scores also presented significant differences between the mean of the first assessment $(13.5, \pm 1.2)$ and last assessment $(12.5, \pm 1.9)$, whose minimum value dropped from 11 to 8 , and maximum value, from 16 to 15 ( $\mathrm{p}=0.034$ ).

Wound healing was assessed based on the comparison of the first and last PUSH score. Six (40\%) of the PUs presented positive healing processes, with a 3.5 -point reduction in mean score (initial: 14; final: 11.5). Only 1 (6.7\%) presented negative evolution, with a one-point increase in mean scores (initial: 14; final: 15), and most of the wounds $(8,53.3 \%)$ maintained the same PUSH score, with a mean of 13. The amount of materials used in the observed dressing procedures $(\mathrm{n}=75)$ and the total direct cost of each item are presented in Table 1.

Table 1 - Total cost of materials used in dressing procedures - Teresina, Piauí, Brazil, 2016.

\begin{tabular}{|c|c|c|c|c|c|c|}
\hline \multirow{2}{*}{ Materials } & \multirow{2}{*}{ Unit } & \multicolumn{3}{|c|}{ Quantity } & \multicolumn{2}{|c|}{ Total cost (USD) } \\
\hline & & n $(\%)^{*}$ & Min-Max & $\mathrm{M}( \pm \mathrm{SD})$ & Min-Max & $\mathrm{M}( \pm \mathrm{SD})$ \\
\hline Needle & - & $59(100)$ & $0.0-13.0$ & $4.0(2.8)$ & $0.0-1.1$ & $0.3(0.2)$ \\
\hline $0.9 \%$ saline solution & $100 \mathrm{ml}$ & $48(100)$ & $0.0-5.0$ & $3.2(1.2)$ & $0.0-1.9$ & $1.2(0.4)$ \\
\hline $0.9 \%$ saline solution ampoule & $10 \mathrm{ml}$ & $70(100)$ & $0.0-15.0$ & $4.7(3.6)$ & $0.0-1.9$ & $1.2(0.5)$ \\
\hline Scalpel and safety handle & - & $21(100)$ & $1.0-2.0$ & $1.4(0.5)$ & $0.8-1.6$ & $1.1(0.4)$ \\
\hline Procedure gloves & Pair & $77(100)$ & $5.0-6.0$ & $5.1(0.4)$ & $0.5-0.5$ & $0.4(0.0)$ \\
\hline Surgical gloves & Pair & $75(100)$ & $5.0-5.0$ & $5.0(-)$ & $1.2-1.2$ & $1.2(-)$ \\
\hline Sterile gauze & 20-unit pack & $121(100)$ & $5.0-12$ & $8.0(2.8)$ & $1.0-2.3$ & $1.6(0.5)$ \\
\hline Micropore tape & $\mathrm{cm}$ & $5265(100)$ & $175.0-460.0$ & $351.0(76.6)$ & $0.2-0.3$ & $0.3(0.5)$ \\
\hline EFA & $\mathrm{ml}$ & $280(100)$ & $0.0-81.00$ & $18.7(20.7)$ & $0.0-0.6$ & $0.2(0.2)$ \\
\hline Papain 8\% & $\mathrm{g}$ & $83(100)$ & $0.0-26.0$ & $5.5(8.6)$ & $0.0-2.3$ & $0.5(0.8)$ \\
\hline Papain 10\% & g & $165(100)$ & $0.0-31.0$ & $11.0(10.6)$ & $0.0-2.5$ & $0.9(0.8)$ \\
\hline Silver Sulfadiazine & g & $43(100)$ & $0.0-30.0$ & $2.9(8.2)$ & $0.0-0.5$ & $0.1(0.1)$ \\
\hline Sterile gauze compresses & 5-unit pack & $22(100)$ & $0.0-7.0$ & $1.5(2.4)$ & $0.0-19.1$ & $4.0(6.5)$ \\
\hline Total & - & $75(100)^{* *}$ & - & - & $5.2-27.7$ & $11.9(7.4)$ \\
\hline
\end{tabular}

Legend: M $( \pm \mathrm{SD})$ : mean and standard deviation; Min-Max: minimum and maximum costs; *Used on all of the observed patients; **total dressing procedures performed. Note: $(n=75)$.

Cost calculation considered the amount of materials used in each dressing procedure per observation and their unit value. The highest costs were associated with sterile compresses (USD 4.0, \pm 6.5 ) and the values of topical treatments varied between USD 0.1 to 0.9 . Maximum total cost was USD 27.7, with a mean of $11.9( \pm 7.4)$, as shown in Table 1 . Table 2 presents costs by PU stage.

The total cost of dressing materials, considering the five observations conducted per patient, was higher among stage 4 ulcers, with a mean of USD 27.7, followed by stage 3 ulcers, with USD 14.1. The minimum value of stage 2 ulcers was USD 1.3 higher than stage 3 ulcers, and the maximum was USD 11.1 lower.
The difference between the mean costs of stage 2 and 3 ulcers was USD 5.9 and no statistically significant differences were observed in the total overall cost among PU categories $(\mathrm{p}=0.252)$ (Table 2). Table 3 presents a comparison between the total cost of PU care $(15,100 \%)$ at the first and last assessments.

Wounds with slough tissue presented a one-unit increase $(1,6.7 \%)$, however dressing-related expenses decreased USD $1.4(\mathrm{p}=0.028)$. Those with necrotic tissue presented a 5 -unit reduction (33.3\%) and the mean total cost of dressings dropped USD 1.7 between the initial and final assessments $(\mathrm{p}=0.036)$. The costs of materials used on wounds with absent exudate decreased USD 1.7 ( $\mathrm{p}=0.018)$, and in quantity 6 (40\%). 
Table 2 - Total cost of dressing materials by stage of pressure ulcer - Teresina, Piauí, Brazil, 2016.

\begin{tabular}{|c|c|c|c|}
\hline \multirow{2}{*}{ Stage of pressure ulcer } & \multirow{2}{*}{$n(\%)$} & \multicolumn{2}{|c|}{ Total cost (USD) } \\
\hline & & Min-Max & $\mathrm{M}( \pm \mathrm{SD})$ \\
\hline Stage 2 & $6(40.0)$ & $6.5-13.1$ & $8.2(2.4)$ \\
\hline Stage 3 & $6(40.0)$ & $5.2-24.2$ & $14.1(8.4)$ \\
\hline Stage 4 & $1(6.7)$ & $27.7-27.7$ & $27.7(-)$ \\
\hline Unstageable & $2(13.3)$ & $7.8-9.0$ & $8.4(0.9)$ \\
\hline Total & 15 (100) & $5.2-27.7$ & $11.9(7.4)$ \\
\hline
\end{tabular}

Legend: $\mathrm{M}( \pm \mathrm{SD})$ : mean and standard deviation; Min-Max: minimum and maximum costs. Note: $(\mathrm{n}=15)$.

Table 3 - Comparison of total costs at initial and final assessments by PU characteristics and PUSH score - Teresina, Piauí, Brazil, 2016.

\begin{tabular}{|c|c|c|c|c|c|c|c|}
\hline \multirow{3}{*}{ Characteristic } & \multicolumn{3}{|c|}{ Initial } & \multicolumn{3}{|c|}{ Final } & \multirow{3}{*}{ p-value } \\
\hline & \multirow{2}{*}{ n (\%) } & \multicolumn{2}{|c|}{ Total cost (USD) } & \multirow{2}{*}{ n (\%) } & \multicolumn{2}{|c|}{ Total cost (USD) } & \\
\hline & & Min-Max & $\mathrm{M}( \pm \mathrm{SD})$ & & Min-Max & $\mathrm{M}( \pm \mathrm{SD})$ & \\
\hline \multicolumn{8}{|c|}{ Tissue type } \\
\hline Epithelial & - & - & - & $1(6.7)$ & $0.7-0.7$ & $0.7(-)$ & $-*$ \\
\hline Granulation & $1(6.7)$ & $2.7-2.7$ & $2.7(-)$ & $4(26.6)$ & $1.1-4.0$ & $1.9(1.4)$ & $0.068^{\mathrm{u}}$ \\
\hline Slough & $6(40.0)$ & $1.1-5.5$ & $3.4(2.0)$ & $7(46.7)$ & $0.7-4.5$ & $2.0(1.7)$ & $0.028^{\mathrm{u}}$ \\
\hline Necrotic & $8(53.3)$ & $1.1-4.4$ & $2.4(1.3)$ & $3(20.0)$ & $0.8-1.1$ & $0.7(0.2)$ & $0.036^{\mathrm{u}}$ \\
\hline \multicolumn{8}{|c|}{ Exudate amount } \\
\hline None & $7(46.7)$ & $1.4-5.5$ & $2.4(1.5)$ & $1(6.7)$ & $0.7-0.7$ & $0.7(-)$ & $0.018^{\mathrm{u}}$ \\
\hline Light & $5(33.3)$ & $1.1-5.1$ & $2.4(1.6)$ & $12(80.0)$ & $0.7-4.5$ & $1.6(1.4)$ & $0.080^{\mathrm{u}}$ \\
\hline Moderate & $3(20.0)$ & $4.3-5.0$ & $4.6(0.4)$ & $2(13.3)$ & $1.4-4.0$ & $2.7(1.9)$ & $0.280^{\mathrm{u}}$ \\
\hline Wound surface area & $15(100)$ & $1.1-5.5$ & $3.3(1.6)$ & 15 (100) & $0.7-4.5$ & $2.4(1.7)$ & $0.002^{t}$ \\
\hline $4.1-8.0 \mathrm{~cm}^{2}$ & - & - & - & $2(13.3)$ & $0.7-1.1$ & $0.9(0.3)$ & $-*$ \\
\hline $8.1-12.0 \mathrm{~cm}^{2}$ & $2(13.3)$ & $1.5-5.0$ & $3.2(2.5)$ & $2(13.3)$ & $0.7-1.1$ & $0.9(0.3)$ & $0.180^{\mathrm{u}}$ \\
\hline $12.1-24 \mathrm{~cm}^{2}$ & $2(13.3)$ & $1.4-2.3$ & $1.8(0.6)$ & - & - & - & $-*$ \\
\hline$>24 \mathrm{~cm}^{2}$ & $11(73.4)$ & $1.1-5.5$ & $2.9(1.6)$ & $11(73.4)$ & $0.8-4.5$ & $1.9(1.6)$ & $0.008^{\mathrm{u}}$ \\
\hline PUSH & $15(100)$ & $1.1-5.5$ & $2.9(1.5)$ & $15(100)$ & $0.7-4.5$ & $1.7(1.4)$ & $0.001^{t}$ \\
\hline \multicolumn{8}{|c|}{ Exudate aspect } \\
\hline Absent & $7(46.7)$ & $1.4-5.5$ & $2.4(1.5)$ & $1(6.7)$ & $0.7-0.7$ & $0.7(-)$ & $0.020^{\mathrm{u}}$ \\
\hline Serous & $1(6.7)$ & $5.0-5.0$ & $5.0(-)$ & - & - & - & -* \\
\hline Sanguineous & $2(13.3)$ & $1.1-4.6$ & $2.7(2.3)$ & $3(20.0)$ & $0.7-4.0$ & $1.3(1.7)$ & $0.180^{\mathrm{u}}$ \\
\hline Serosanguineous & $5(33.3)$ & $1.1-5.0$ & $3.0(1.7)$ & $11(73.3)$ & $0.8-4.5$ & $1.1(0.3)$ & $0.043^{\mathrm{u}}$ \\
\hline \multicolumn{8}{|c|}{ Wound odor } \\
\hline Present & $1(6.7)$ & $4.3-4.3$ & $4.3(-)$ & - & - & - & $-*$ \\
\hline Absent & $14(93.3)$ & $1.1-5.5$ & $2.7(1.6)$ & $15(100)$ & $0.7-4.5$ & $1.1(0.6)$ & $0.001^{\mathrm{u}}$ \\
\hline \multicolumn{8}{|c|}{ Change frequency } \\
\hline Once a day & $11(73.3)$ & $1.1-5.5$ & $2.7(1.7)$ & $12(80.0)$ & $0.7-4.5$ & $1.1(0.3)$ & $0.004^{\mathrm{u}}$ \\
\hline Twice a day & $4(26.7)$ & $1.4-4.4$ & $3.2(1.4)$ & $3(20.0)$ & $0.7-4.0$ & $0.8(1.9)$ & $0.140^{\mathrm{u}}$ \\
\hline Total & $15(100)$ & $1.1-5.5$ & $2.8(1.6)$ & $15(100)$ & $0.7-4.5$ & $1.1(0.5)$ & $0.002^{t}$ \\
\hline
\end{tabular}

Legend: M ( $\pm \mathrm{SD})$ : mean and standard deviation; Min-Max: minimum and maximum costs; t: significance of Student's t-test; u: significance of the Wilcoxon Signed-Rank test; *Insufficient number of valid decimal places to conduct test. Note: $(\mathrm{n}=15)$.

Regarding wound surface area, between initial and final assessment, there were statistically significant differences in total costs $(\mathrm{p}=0.002)$. Furthermore, throughout the same interval, PUSH scores decreased USD 1.2 ( $\mathrm{p}=0.001)$. In PUs with serosanguineous exudate, the difference was USD 1.9 ( $\mathrm{p}=0.043)$.

Significant differences were also found in wounds with no odor, in which dressing-related costs decreased USD 1.6 $(\mathrm{p}=0.001)$, and in the frequency of one dressing change per day, with a USD 1.6 difference $(\mathrm{p}=0.004)$ between the first and last assessment. For dressings changed every two days, the initial mean cost with materials was four times greater than the last assessment, however, the difference was not statistically significant. The mean total cost between assessments presented a statistically significant reduction of USD 1.7 between assessments ( $\mathrm{p}=0.002)$, corresponding to $60.7 \%$ of the initial value (Table 3 ).

\section{DISCUSSION}

Cost assessment of dressing materials was associated with PU characteristics. The indicators measured through the PUSH scale demonstrated an overall improvement in wound healing. The positive evolution of the wounds in this study was associated with significant cost reduction.

High incidence and prevalence rates of $\mathrm{PU}$ in critical care patients significantly impact health service costs. A 
prospective cohort study identified that the amount of PUs was positively correlated with wound care costs in intensive care units ${ }^{(11)}$.

The study sample (15 patients) was composed mainly by women, with incomplete elementary education. However, studies conducted in intensive care units with samples of 40 to 563 patients, reported a higher incidence among male patients $^{(11-12)}$,even though there was no statistically significant difference between treatment costs and gender. It is worth mentioning that lower education levels may compromise patient understanding of the orientations provided by the multiprofessional health team during hospital stay or at discharge.

Among the comorbidities presented, the most predominant were systemic arterial hypertension and diabetes mellitus. The most significant risk factors for developing PU are immobility, skin aspect (dryness, erythema, and pre-existing injuries), and blood perfusion. A vital sign that is compromised in patients with diabetes and vascular, circulatory and pressure disorders, as altered blood flow can lead to ischemia and the development of ulcers, in addition to delaying the healing process ${ }^{(13-14)}$.

Another risk factor to consider is the participants' nutritional condition, as $26.6 \%$ were at nutritional risk. Good nutrition is essential to $\mathrm{PU}$ prevention. There is evidence suggesting improvement of wound healing in patients in good nutritional conditions, and positive effects are observed when nutritional interventions are conducted during PU treatment ${ }^{(15-16)}$.

The fact that all patients were bedridden may have contributed to the emergence of PUs, all located in the sacral region. Being bedridden reduces the ability to relieve pressure on bony prominences, maintaining pressure intensity and duration $^{(13)}$, even with the use of pneumatic mattresses with pressure redistribution surfaces that reduce the probability of ulcer formation ${ }^{(17)}$. It is worth mentioning the importance of position changes according to patients' clinical conditions, $30^{\circ}$ backrest elevation, daily skin assessment and the use of dietary supplements in PU prevention and treatment ${ }^{(10,18)}$.

There was a considerable reduction in PUSH scores and mean wound surface area between the first and last assessments. Assessment of the PUSH scores demonstrated that although most of the PUs maintained the same healing level, some improved in the assessment interval. This finding shows that, in general, the wounds presented positive healing processes.

However, wound healing cannot be attributed solely to wound care dressing. The process of PU development is multifactorial, including environmental and patient-specific variables. The influence of environmental variables can be intensified by the nursing team care management and the institution's structural characteristics ${ }^{(19)}$.

Pressure ulcer treatment includes the use of dressings, and among the materials seen in this study, some were elementary and present in all the observations, such as procedure gloves, sterile gloves, sterile gauze, $0.9 \%$ saline solution and micropore tape. Procedure gloves are personal protection equipment and were used in this study to remove previous dressings; the sterile gloves were used to reduce the probability of wound contamination by exogenous infectious agents.
Saline solutions were used to clean wounds either by moistening dressings or direct applying the solution in spurts. Gauze was used as primary and secondary dressings, protecting the wound against the action of exogenous agents, which justifies its intense use. In general, PUs are open wounds that require occlusive dressings, hence the importance of treatment materials ${ }^{(12)}$.

Sterile compresses were used less frequently on wounds; however, when used, they implied significantly increased costs, contributing to higher mean total costs. The compresses used in the facility, acquired through procurement, came in packs of five. Every time a compress was necessary, a new pack was opened and unused compresses had to be discarded.

Industrialized wound dressings were not used in the observed procedures, only topical treatments, such as the use of essential fatty acids (EFA), papain, and silver sulfadiazine. Linoleic and linolenic acids are the most important fatty acids for wound treatment and, in general, they are applied on wounds with granulation tissue. There is no strong scientific evidence establishing the effectiveness of EFA in wound healing among humans ${ }^{(20)}$. However, it is widely used in Brazil in wound prevention and treatment, possibly for cultural and economic reasons.

In this study, only two papain concentrations were available, $8 \%$ and $10 \%$, which made it difficult to choose the best option. Papain can be applied in wound debridement and presents anti-inflammatory action, helping wound edges contract and pull together through healing by second intention. It is available in different concentrations according to wound tissue type ${ }^{(21)}$. Nurses are responsible for constantly assessing wounds and selecting suitable dressings for treatment, which promote healing and cure.

Silver sulfadiazine is an antibacterial and antifungal drug based on the activity of $\mathrm{Ag}^{+}$ions. It can be applied in a wide range of conditions, and is effective against Pseudomonas aeruginosa. This topical treatment is usually used in burn patients to help prevent and treat wound infections ${ }^{(22)}$.

The mean total cost of dressing materials was considerable, even without the use of industrialized dressings, which vary in cost and depend on the size and severity of $\mathrm{PU} \mathrm{U}^{(23)}$. Pressure ulcers take a long time to heal, so despite the apparent low unit cost of the materials used, when multiplied by the number of times used, PU generate high costs for hospitals. Furthermore, inadequate use of the materials leads to waste, which is not necessarily related to using more than is needed, as low expenditure coupled with poor use can also lead to waste ${ }^{(24)}$.

Regarding cost assessment, lower values were observed among stage 4, stage 3, nonstageable and stage 2 ulcers, in this order. Classification of PU by stages represents one of the reference characteristics when assessing dressing costs. In general, costs are directly proportional to stage of PU, being that the greater the severity of wounds, the higher the costs. This is due to the association between stage 4 ulcers and higher costs of materials, longer treatment, greater amount needed, and higher incidence of complications ${ }^{(25)}$.

The total mean cost of unstageable PUs was between the average cost found in stage 2 and 3. This finding corroborates 
a study developed in Canada in 1,000 hospitals with a sample of 3,874 PUs, in which the cost of hospital-acquired unstageable PUs also fell between these two PU categories, while the total average cost of PUs developed before admission was lower than that of stage $2^{(26)}$. The data indicate lack of linearity in treatment costs associated with nonstageable ulcers. This absence of proportionality may be due to the variability of characteristics presented by these types of PU, in which there is no standardized procedure.

The comparison between the initial and final costs of wound dressing material revealed a statistically significant cost reduction between one assessment and the other. This finding may be attributed to the clinical improvement of PUs, which consequently led to fewer necessary materials and dressing changes. The costs of PU treatment were directly correlated with the healing stage and aspect of wound bed.

One of the main factors influencing costs was the frequency of dressing changes. In this study, dressings were changed daily, primarily once a day. Dressing changes depend on the presence of infection, type of dressing, wound location, and exudate amount ${ }^{277}$. Furthermore, traditional dressings require more frequent changes in comparison with industrial dressings, which present higher levels of evidence as to the effectiveness of wound healing over shorter periods of time and that contribute to cost reduction ${ }^{(28)}$.

The average cost of the materials used presented a significant difference between the first and last assessments, dropping $60.7 \%$ between one and the other. Quick PU healing may contribute to cost savings for health systems; however, there are few studies that expressively analyze the cost-benefit relationship of prophylactic and curative measures to reduce PU incidence or improve treatment outcomes and the quality of life of critical patients ${ }^{(26,28)}$.

In addition to direct costs, which correspond to the material and human resources that are immediately required in interventions, there are also indirect costs. These are of a social nature, associated with loss of work productivity due to illness and the time required to heal chronic wounds, such as stage 3 and 4 PUs. Indirect costs also include working days lost, patient pain and suffering, and the consequential negative impact on the quality of life and expenses of patients and their family members ${ }^{(6)}$.

Some PUs improved, as indicated by lower PUSH scores and reduced costs. However, in general, on considering the assessment interval (20 days), treatment may not have been significant if a broader verification interval had been used. Both conditions can determine the relationship between treatment and costs with dressing materials.

Limitations of this study include its sample size, which does not allow for the generalization of results, and the number of observations, which did not include all the dressings performed throughout the entire PU treatment span. Additionally, the institution did not work with industrialized dressings, an organizational factor that limited the comparison of different treatment techniques and options. The data were explored especially within a technical context, considering the scarce production of articles with clear stratified calculations to determine the cost of wound-dressing materials.

\section{CONCLUSION}

The present study showed a proportional relationship between cost and PU stage, in that the more severe the injury, the higher the cost of treatment. Furthermore, a statistically significant cost reduction was observed between the initial and final observation. Most of the wounds remained stable in terms of PUSH scores, however, when considering wound characteristics, a positive healing process was observed.

This improvement cannot be attributed solely to wound care dressing, but also to a set of factors that involve patientspecific and environmental characteristics. Nurses have an important role in creating plans and developing protocols to guide and systematize evidence-based care to improve PU care management in hospitals.

\section{RESUMO}

Objetivo: Avaliar o custo direto com curativos no tratamento de lesões por pressão. Método: Estudo observacional descritivo, realizado em Unidade de Terapia Intensiva do nordeste do Brasil, de novembro a dezembro de 2015. Foi aplicada a Pressure Ulcer Scale for Healing e formulário para caracterização e avaliação de custos. Os valores da moeda brasileira (R\$) foram convertidos para a moeda norte-americana (US\$) à taxa de US $\$ 0,26 / \mathrm{R} \$$. Foram realizadas análises univariadas e bivariadas. Resultados: Compuseram a amostra 15 pacientes com lesões, no mínimo, estágio 2 . Houve redução significativa dos custos com materiais de curativos entre as avaliações inicial e final ( $\mathrm{p}=0,002)$, com média de US $\$ 11,9( \pm 7,4)$. As terapias tópicas mais frequentes foram ácidos graxos essenciais e papaína. Conclusão: Verificou-se redução de custos proporcional aos estágios das lesões. Enfatiza-se o papel do enfermeiro na elaboração de planos de cuidados baseados em evidências para melhor gerenciamento do cuidado.

\section{DESCRITORES}

Úlcera por Pressão; Custos e Análise de Custo; Bandagens; Cuidados de Enfermagem.

\section{RESUMEN}

Objetivo: Evaluar el costo directo de curativos para el tratamiento de lesiones por presión. Método: Estudio observacional descriptivo en la Unidad de Cuidados Intensivos del noreste de Brasil, de noviembre a diciembre del año 2015. Se aplicó la Pressure Ulcer Scale for Healing y formulario para la caracterización y evaluación de los costos. Los valores de la moneda brasileña (Reales- R $\$$ ) se convirtieron al dólar estadounidense (US\$) a razón de $\$ 0.26 / \mathrm{R} \$$. Se realizaron análisis univariados y bivariados. Resultados: La muestra consistió en 15 pacientes con lesiones al menos en Etapa 2. Hubo una reducción significativa en el costo de los materiales de curación entre las evaluaciones inicial y final ( $\mathrm{p}=0,002)$, con un promedio de US $\$ 11.9( \pm 7.4)$. Los tratamientos tópicos más comunes son los ácidos grasos esenciales y papaína. Conclusión: Se verificó una reducción de los costos proporcional a las etapas de las lesiones. Se hace hincapié en el papel de los enfermeros en el desarrollo de planes de cuidados basados en la evidencia, para una mejor gestión de la atención.

\section{DESCRIPTORES}

Úlcera por Presión; Costos y Análisis de Costo; Vendajes; Atención de Enfermería. 


\section{REFERENCES}

1. Mallah Z, Nassar N, Kurdahi BL. The effectiveness of a pressure ulcer intervention program on the prevalence of hospital acquired pressure ulcers: controlled before and after study. Appl Nurs Res. 2015;28(2):106-13.

2. Moraes JT, Borges EL, Lisboa CR, Cordeiro DC, Rosa EG, Rocha NA. Conceito e classificação de lesão por pressão: atualização do National Pressure Ulcer Advisory Panel. Rev Enferm Cento Oeste Min. 2016;6(2):2292-306.

3. Whitlock E, Jenny M, Geoffrey S, Tina J, Seamus R. Wound care costs in general practice: a cross-sectional study. Aust Fam Physician. 2014;43(3):143-6.

4. Silva L, Schutz V, Machado D. Partial assessment of the cost of dressings performed at an intensive care unit. Rev Enferm UFPE On Line [Internet]. 2015 [cited 2016 Feb 18];9(3):7031-8. Available from: http://www.revista.ufpe.br/revistaenfermagem/index.php/revista/article/ view/7194/pdf_7361

5. Palfreyman SJ, Stone PW. A systematic review of economic evaluations assessing interventions aimed at preventing or treating pressure ulcers. Int J Nurs Stud. 2015;52(3):769-88.

6. Packeiser PB, Resta DG. Farmacoeconomia: uma ferramenta para gestão dos gastos com medicamentos em hospitais públicos. Infarma [Internet]. 2014 [citado 2016 mar. 11];26(4):215-23. Disponível em: http://oaji.net/articles/2016/3425-1470059452.pdf

7. Mata VE, Schutz V, Peregrino AA. Dificultades y oportunidades para la enfermería: una revisión narrativa sobre evaluación económica en salud. Enferm Global [Internet]. 2013 [citado 2016 Mar. 30];12(29):392-403. Disponible en: http://revistas.um.es/eglobal/article/ view/134651/144261

8. Khalatbari-Soltani S, Marques-Vidal P. Impact of nutritional risk screening in hospitalized patients on management, outcome and costs: a retrospective study. Clin Nutr. 2016;35(6):1340-6.

9. Silveira SLP, Silva GRF, Moura ECC, Rangel EML, Sousa JERB. Avaliação das lesões por pressão por meio da aplicação da escala pressure ulcer scale for healing (PUSH). Rev Pesqui Cuid Fundam. 2013;5(2):3847-55.

10. National Pressure Ulcer Advisory Panel; European Pressure Ulcer Advisory Panel; Pan Pacific Pressure Injury Alliance. Prevention and treatment of pressure ulcers. Cambridge Media: Osborne Park, Western Australia. Clinical Practice Guideline; 2014.

11. Swafford K, Culpepper R, Dunn C. Use of a comprehensive program to reduce the incidence of hospital-acquired pressure ulcers in an intensive care unit. Am J Crit Care. 2016;25(2):152-5.

12. Costa MA, Matozinhos AC, Trigueiro PS, Cunha RC, Moreira LR. Custos do tratamento de úlceras por pressão em unidade de cuidados prolongados emu ma instituição hospitalar de Minas Gerais. Enferm Rev. 2015;18(1):58-74.

13. Coleman S, Gorecki C, Nelson A, Closs JS, Defloor T, Halfens R, et al. Patient risk factors for pressure ulcer development: systematic review. Int J Nurs Stud. 2013;50(7):974-1003.

14. Manorama A, Meyer R, Wiseman R, Bush TR. Quantifying the effects of external shear loads on arterial and venous blood flow: implications for pressure ulcer development. Clin Biomech (Bristol, Avon). 2013;28(5):574-8.

15. Leaker SH. The role of nutrition in preventing pressure ulcers. Nurs Stand. 2013;28(7):16-22.

16. Choo TS, Hayter M, Watson R. The effectiveness of nutritional intervention(s) and the treatment of pressure ulcers: a systematic literature review. Int J Nurs Pract. 2013;19 Suppl 1:S19-27.

17. Pinho CM, Correia RN, Valença MP, Cavalcanti ATA, Gomes ET. Use of the air mattress in the reduction of pressure ulcers: efficacy and perceptions of nursing. Rev Enferm UFPE On Line [Internet]. 2014 [cited 2016 Mar 11];8(8):2729-35. Available from: http://www.revista. ufpe.br/revistaenfermagem/index.php/revista/article/view/5337

18. Cooper KL. Evidence-based prevention of pressure ulcers in the intensive care unit. Crit Care Nurse. 2013;33(6):57-66.

19. Benoit R, Mion L. Risk factors for pressure ulcer development in critically ill patients: a conceptual model to guide research. Res Nurs Health. 2012;35(4):340-62.

20. Ferreira AM, Souza BM, Rigotti MA, Loureiro MR. The use of fatty acids in wound care: an integrative review of the Brazilian literature. Rev Esc Enferm USP. 2012;46(3):752-60.

21. Leite AP, Oliveira BG, Soares MF, Barrocas DL. Use and effectiveness of papain in the wound healing process: a systematic review. Rev Gaúch Enferm. 2012; 33(3):198-207.

22. Souza GD, Rodrigues MA, Silva PP, Guerra W. Prata: breve histórico, propriedades e aplicações. Educ Quím. 2013;24(1):14-16.

23. Andrade CC, Almeida CF, Pereira WE, Alemão MM, Brandão CM, Borges EL. Costs of topical treatment of pressure ulcer patients. Rev Esc Enferm USP. 2016;50(2):292-8. DOI: http://dx.doi.org/10.1590/S0080-623420160000200016

24. Castilho V, Castro LC, Couto AT, Maia FO, Sasaki NY, Nomura FH, et al. Survey of the major sources of waste in the health care units of a teaching hospital. Rev Esc Enferm USP. 2011;45(n.spe):1613-20.

25. Dealey C, Posnett J, Walker A. The cost of pressure ulcers in the United Kingdom. J Wound Care. 2012;21(6):261-6.

26. Chan B, leraci L, Mitsakakis N, Pham B, Krahn M. Net costs of hospital-acquired and pre-admission PUs among older people hospitalised in Ontario. J Wound Care. 2013;22(7):341-6.

27. Sood A, Granick MS, Tomaselli NL. Wound dressings and comparative effectiveness data. Adv Wound Care. 2014;3(8):511-29.

28. Silva AJ, Pereira SM, Rodrigues A, Rocha AP, Varela J, Gomes LM, et al. Economic cost of treating pressure ulcers: a theoretical approach. Rev Esc Enferm USP. 2013;47(4):967-72. 